in using preventive measures supplied to them. Following the above investigation of industrial eye injuries he has organised at the Royal Eye Hospital a museum of preventive measures at the hospital outpatient rooms. The patients have thus an opportunity of studying the preventive appliances at the time of attendance at the hospital and thus choosing the most suitable one for their type of work. If other hospitals situated in industrial centres will take an interest in preventive work, a diminution of eye injuries and with it of its resultant total or partial blindness would follow.

Mr. Lewis H. Carris (U.S.A.) read a paper on the rôle of the social worker in a prevention of blindness campaign. Educators, public health officials, nurses, industrialists, sanitary engineers, social workers and all in any way concerned in human welfare must take their rightful place in this attack upon this social enemy. To the world at large we must teach the causes of blindness and of defective vision, the place of nutrition and hygiene in relation to eye health, methods of safeguarding the eye aginst injury and harm and of keeping it in a state of greatest possible usefulness

\title{
INTERNATIONAL ORGANIZATION AGAINST TRACHOMA
}

\section{Executive Committee}

A Meeting of the Executive Committee was held on December 9, 1937, at the Semiramis Hotel, Cairo.

The Secretary General read the Minutes of the last Meeting of the Executive Committee held in Paris in 1936. The accounts were examined and found to be correct. The subvention given for purposes of research by the American Academy of Ophthalmology and Oto-Laryngology, 100 dollars, was allocated to Dr. Poleff of the Pasteur Institute at Rabat, Morocco. It was decided to hold the next meeting of the Organization at the same place, and at the same time, as the next Meeting of the International Council of Ophthalmology in the year 1939.

\section{Assembly of Delegates}

An Assembly of delegates was held on December 10, 1937, at the Semiramis Hotel, Cairo.

A statement was made by the President as to the business to be transacted. The audited accounts were passed. Professor Manuel Marquez was elected an Honorary Member of the Executive Committee. 
The President, Mr. MacCallan, and the Secretary General, Dr. Wibaut, having been elected for a period of five years at the Meeting in London in 1935 remain in office. According to the statutes four members of the executive committee were due to retire in 1935; however, as all members were due to retire by 1937 , it was decided to defer elections until the present time in order to obtain the presence of the maximum number of Delegates.

The President explained that six Nations were already represented on the Executive Committee, as follows :-

\begin{tabular}{|c|c|c|c|}
\hline $\begin{array}{l}\text { Great Britair } \\
\text { Holland }\end{array}$ & & $\begin{array}{l}\text { The President, Mr } \\
\text { - The Secretary Ger }\end{array}$ & $\begin{array}{l}\text { MacCallan. } \\
\text { eral, Dr. Wibaut. }\end{array}$ \\
\hline $\begin{array}{l}\text { France } \\
\text { U.S.A. }\end{array}$ & & $\begin{array}{ll}\text { - Dr. Bailliart } \\
\text { - Dr. Park Lewis }\end{array}$ & $\begin{array}{l}\text { Ex-officio as representing } \\
\text { International Association } \\
\text { for Prevention of Blindness }\end{array}$ \\
\hline $\begin{array}{l}\text { Hungary } \\
\text { Spain - }\end{array}$ & & $\begin{array}{l}\text { - Professor de Grosz } \\
\text { - Professor Marquez }\end{array}$ & Honorary Members. \\
\hline
\end{tabular}

There being twelve vacancies on the Committee it was proposed by the President that twelve Nations should be represented other than those previously mentioned, and that each national representative should be selected by each national group. Also that as provided in the Statutes no distinction should be made as to grades of Vice-Presidents, Members and Secretary. This was agreed to.

It was then proposed, seconded and carried that the following Nations, as being the most trachomatous, should be represented on the Executive Committee :-

Argentina; Bulgaria; Czecho-Slovakia; Egypt; Germany; Italy; India; Japan; Lithuania; Poland; Rumania; Turkey.

The Meeting concluded with a vote of thanks to the President.

Subsequently it was announced that the national groups of the above-named countries had selected the following as their representatives:-

$\begin{array}{llll}\text { Argentina } & - & - & \text { Dr. Jose A. Sena. } \\ \text { Bulgaria } & - & - & \text { Prof. Pascheff. } \\ \text { Czecho-Slovakia } & - & \text { Prof. Kadlicky. } \\ \text { Egypt - } & - & - & \text { Dr. Tewfik. } \\ \text { Germany } & - & - & \text { Prof. Rohrschneider. } \\ \text { Italy - } & - & - & \text { Prof. Leonardi. } \\ \text { India - } & - & - & \text { Dr. Mukerjee. } \\ \text { Japan - } & - & - & \text { Prof. Oguchi. } \\ \text { Lithuania } & - & - & \text { Dr. Avizonis. } \\ \text { Poland - } & - & - & \text { Dr. Zachert. } \\ \text { Rumania } & - & - & \text { Prof. Michail. } \\ \text { Turkey - } & - & - & \text { Dr. Naci Bengisu. }\end{array}$




\section{The Scientific Meeting}

Held at the Semiramis Hotel, Cairo, on December 10, 1937.

(1) Introductory address by the President, Mr. MacCallan.

(2) The microbiological aetiology of trachoma :-

Reporters: Dr. Phillips Thygeson, Prof. Dr. Grüter, Prof. Dr. Oguchi, Drs. Cuénod and Nataf (in their absence an abstract was read by Dr. Farhat), Dr. Rötth, Dr. Julianelle (in his absence an abstract was read by Major Stewart).

Discussion; Major Stewart, Prof. Dr. Igersheimer, Dr.Taborisky, Dr. Postic, Prof. Dr. Favoloro, Dr. Gomez Marquez.

(3) The pathology of trachoma:-

Reporters: Dr. Wilson, Prof. Dr. Michail, Prof. Dr. MulockHouwer, Prof. Dr. Pascheff, Dr. Busacca.

Discussion : Prof. Dr. Lauber, Dr. Rötth.

(4) The treatment of trachoma :-

Reporters: Dr. Sobhy Bey, Dr. Shimkin.

Discussion: Prof. Dr. Sabadini, Prof. Dr. Preciosi, Dr. Narog, Dr. Gomez Marquez.

(5) Independent communications :-

Prof. Dr. Motegi: "The epidemiology of trachoma in Japan."

Dr. Lijo-Pavia: "Trachoma among school children in Buenos Aires." (Abstract read by Dr. Bertotto.)

Discussion : Prof. Dr. Barriere, Dr. Sena.

Dr. Zachert: "Application of the ophthalmoscope for the diagnosis of trachoma."

Dr. Sarnelli : "Influence of radiation on trachoma."

Discussion: Prof. Dr. Parparcone.

Dr. Jacovides: "My ideas on trachoma."

Dr. Hassouna: "Treatment of trachoma by tuberculin."

Dr. Charamis: "Plan of a new ophthalmic hospital at Athens."

\section{COUNCIL OF BRITISH OPHTHALMOLOGISTS}

\section{Report on Standards of Vision for Candidates for Scholarships and Teacherships under Local Educational Authorities}

THE Council appointed the following Committee to review and report on the Standards of Vision required of Candidates for Scholarships and Teacherships under local Educational Authorities which have been in force since 1924 :- The President and Hon. Secretary (ex-officiis), with Sir Arnold Lawson, Messrs. Percy Flemming, Bishop Harman, A. C. Hudson, P. G. Doyne, W. H. McMullen and Dr. Wiley. 